\title{
SACCADIC EYE MOVEMENT IN NORMAL INDIVIDUALS
}

\author{
YO KIMURA, M. D., ISAO KATO, M. D., YOSHIO KOIKE, M. D. \\ Department of Otolaryngology, Yamagata University, Yamagata \\ (Director: Y. Koike, M. D.) \\ YUKIO WATANABE, M. D. \\ Department of Otolaryngology, Niigata University, Niigata \\ (Director: H. Ino, M. D.)
}

Saccadic eye movement test was carried out in twenty-five normal subjects, 12 males and 13 females ranging in age from 21 to 35 year-old, to make quantitative analysis of saccade velocity, duration, amplitude, and latency. Recordings were made with a direct-current electronystagmographic system, and data analysis was performed on a laboratory digital computer (PDP-11/40)

1. The latency (delay time) of saccades was constantly about $260 \mathrm{msec}$, but only the initial saccade occurred within about $480 \pm 190 \mathrm{msec}(\operatorname{mean} \pm \mathrm{S}$. D.) after the target jump.

2. Target jump amplitude and saccade velocity (maximum and average) had a nonlinear relationship that was better fit by an exponential curve.

3. Target jump amplitude and saccade duration and the time of maximum velocity was found to be linearly correlated.

4. Saccade amplitude was more than 95 per cent of the target jump amplitude for each induced saccade.

Accurate assessment of saccades should be a sensitive functional test of the extraocular motor system.

A $82-0647-24022$

\section{衝動 性 眼球運動の定量的分析}

一正常所見について(その 1$)-$
山形大学医学部耳舅咽喉科学教室（主任：小池吉郎教授）
木村洋, 加藤功, 小池吉 郎

新潟大学医学部耳鼻咽喉科学教室 (主任: 猪 初男教授)

渡辺行雄

\section{Iはじめに}

視覚入力による眼球軍動には視軸るるる点よりある点 に変える時に起こる速い，不連称な眼球運動（墅動性眼 球運動)之，ゆっくり動く対象物をみる時江起こる滑ら かて連続的な眼球運動（滑動性眼球伟動）と2 種類あ
る72この眼球運動は生理的, 機能的, 神経機椣など種

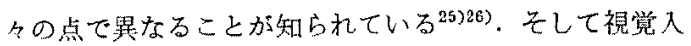
力による眼球運動を指標とした検查法が種々開発され， 神経学、神経耳科学, 神経眼科学などの頜域で広く行な われている，衝動性眼球運動の機能検卒としては跳躍視 
標追跡検查 (Skipping Eye-Tracking Test) の装置の試 作がなされ，大塚 ${ }^{20)}$, 吉本 ${ }^{25226)}$, 和田 ${ }^{27)}$, 五十嵐 ${ }^{19)}$ 等飞 より検討されているが，大方は反応の左右差や反応波形 のパターン等に上り定性的もしくは半定量的に結果を判 定している. しかし, Westheimer ${ }^{15)}$ の最初の定量的分 析につついて Hyde ${ }^{9)}$, Robinson ${ }^{11)}$ らの生理学的研究

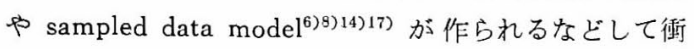
動性眼球運動について神経学的機構の解明むなされてき ている.最近はコンピューターの導入により, 衙動性眼 球運動をより早く正確に定量化できるようになり, 臨床 的飞も応用され始めている ${ }^{122) 3) . ~}$

今回, われわれは衙動性眼球運動の客観化, 定量化に 注目し, 衝動性眼球運動の検查装置を新しく考案したの で22), 本装置を用いて衙動性眼球運動の検查を正常人 25 名について行ない, 小型電算機 $(\mathrm{PDP}-11 / 40)$ を用いて 正常所見について定量的分析を武みた.

\section{II 検查装置と検查方法}

\section{1. 装置 (図 1)}

本装置についての詳練は别著 ${ }^{22)} て ゙$ 述べてあるので 既 略について説明する。

我々の試作した装置はランブ点滅式光刺激装置で, 弧 状の視標板上に 7 個のランプを被検者からみて各々 $10^{\circ}$
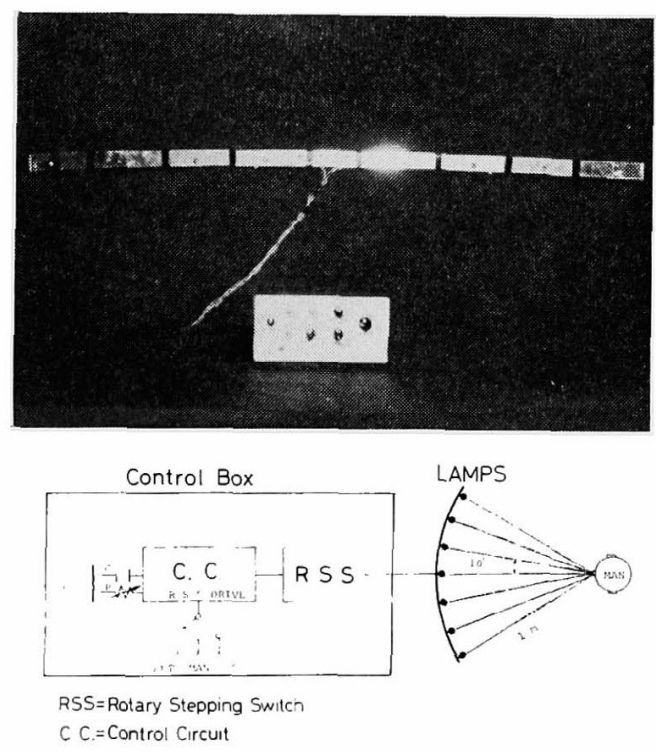

図 1 衙動性眼球運動椧查装置とブロックダイ アグラム
の等視角で最大視角 $60^{\circ}$ となるようと取りつけた．視標 点減順序は制御装置内の rotary stepping switch を用 いて無作為沾隇し，視標振幅は $10^{\circ} \sim 60^{\circ}$ まで可変と した. また視標点滅時間間隔は数 msec〜数sec まで可変 とし,ささらと手動スイッチによる無作為の点滅も可能で ある.1シリーズの視標点堿回数は29回とし 6 通りのプ ログラムを作製し適宜使用した.

\section{2. 検查方法}

神経耳科的および視力, 視野等に異常を認めなかった 21歳から35歳までの男子12名, 女子13名の計25名を選び 被検者とした.

被検者は椅子に坐り，頭部を固定して（図 2），眼前 $1 \mathrm{~m}$ の視標板上のランプを追跡視するように指示した.

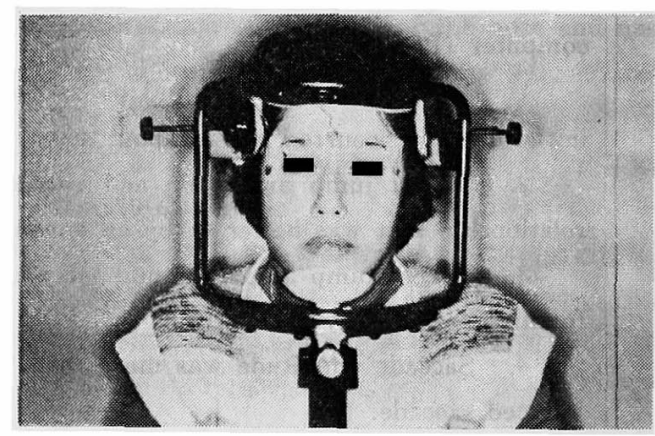

図 2 頭部 固 定 器

検査は, 先ず左右 $10^{\circ}$ (正中 $\rightarrow$ 右 $10^{\circ} \rightarrow$ 正中 $\rightarrow$ 左 $10^{\circ} \rightarrow$ 正中）の較正を行なった後に 1 シリーズ29回の視標の移 動点滅を追跡視させ $\left(10^{\circ} \sim 60^{\circ}\right)$, 終了後再較正を行な った. 今回は視標点滅速度を固定し, 1 被検者につき 3 秒間隔と 2 秒間隔の視標点減速度で行ない, 視標点隇順 芧のプログラムは同一のものを使用した. 検査室の明る さは室内灯点灯下で行なった. な打, 本編では水平方向 の衝動性眼球運動についてのみ検討した.

3. 眼球運動の記録方法

眼球運動の記録は電気眼振計(ENG) を用い high cut filter $25 \mathrm{~Hz}$ で D.C. 記録を行なった. 図 3 亿 ENG 記録された衝動性眼球運動と視標の動きを示した.

ENG に記録された眼球運動括よび視標の動きはENG の外部出力端子からデーターレコーダー（FMテープ記 録）に格納し，この記録を再生して PDP-11/40 電算機 の $\mathrm{AD}$ 変換機（analog to digital converter）飞接続し た. $\mathrm{AD}$ 変換のサンプリング時間は $10 \mathrm{msec}$ とし $1^{\circ}$ の 眼球偏位が電算機の内部值で 40 となるように較正しな 


\section{EYES}

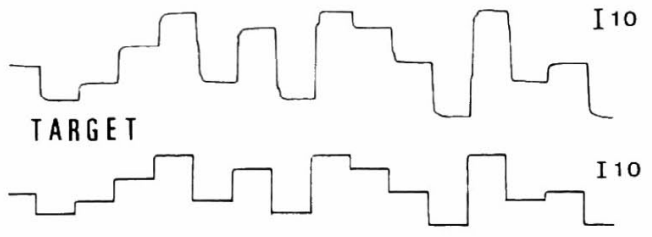

図 3 衝動性眼球運動検査の ENG 記録

上段：眼球運動記録（D. C. 記録）

下段：視標記録

がらサンプリングを行った後，।イズ消去のため下位 2 ビットを切り唅て，1 $1^{\circ}$ を内部值で 10 として磁気ディス クに収納した. 図 4 は実際にコンピューターの画面にデ 1スプレーされた眼球運動と視標の動きを示した.

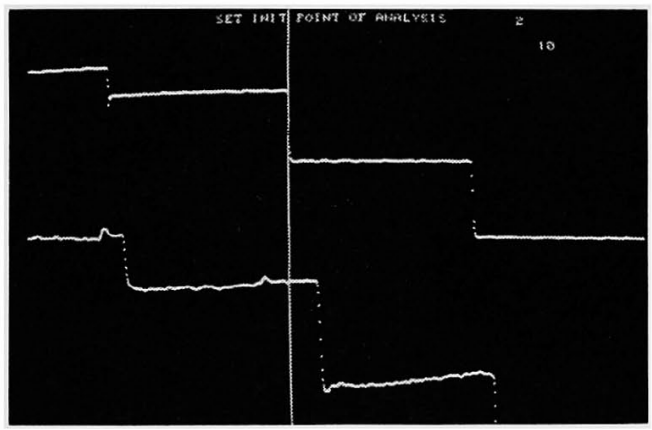

図 4 街動性眼球運動検査のコンピューター两 面におけるディスプレー表示

上段：視標記録

下段: 眼球運動記録

縦線：視標の変曲点を示す

4. データー分析

実際の計測にあっては, 図 5 に示すごとく一つ一つの 視標の動きごとに眼球運動波形をコンピューターの画面 にディスプレーさせ, 衝動性眼球運動の 分析を行なっ た.

われわれは衝動性眼球運動の 定量的分析を行なうた め, コンピュータープログラムを作製し, 以下に示す 6 項目について検討した.

1）潜時 latency：視標の位置の移動開始から衝動性 眼球運動開始までの時問 (図 5,a).

2) 最高速度 maximum velocity：衝動性 眼球運動 における最大眼球速度（図 $5, \tan \theta(\mathrm{deg} / \mathrm{sec}))$.
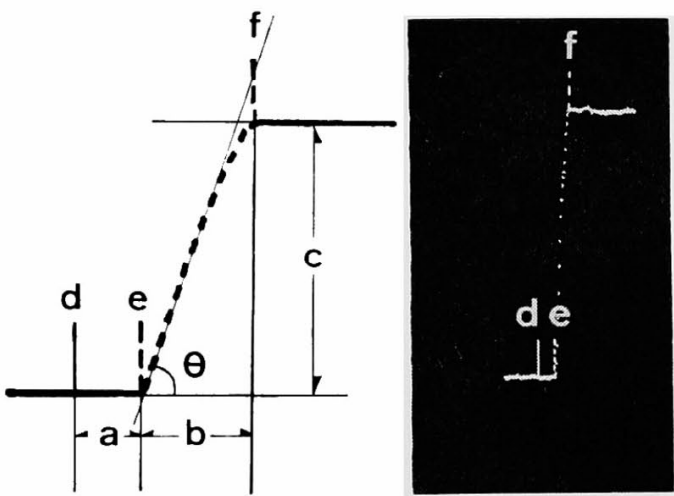

図 5 衝動性眼球運動の計測

$$
\begin{array}{ll}
\mathrm{a}: & \text { 潜 時 } \\
\mathrm{b}: & \text { 持続時間 } \\
\mathrm{c}: & \text { 眼球偏位量 } \\
\mathrm{d}: & \text { 視標の変曲点を示与 } \\
\mathrm{e}: & \text { 衍動性眼球運動の開始点 } \\
\mathrm{f}: & \text { 衝動性眼球運動の終了点 } \\
\text { O: } & \text { 眼球運動の最高速度 } \tan \theta \text { (degrees } / \mathrm{sec})
\end{array}
$$

3) 平均速安 average velocity：衝動性眼球運動の 平均眼球速度 (眼球偏位量/持続時間).

4）持続時間 duration: 衝動性眼球運動閒始加 5次 に点灯した視標に倒達するまでの時閒（図 5,b).

5）最高速度到達時間 time of maximum velocity (MVT)

6) 眼球偏位量 amplitude：点灯した眼標把握の正 確度 (図 $5, c$ ).

なお，正常者においても衝動性眼球運動には図6亿示 すように corrective saccade (図 6,A), two saccade (図 6,B), three saccade (図 6,C), overshoot（図 6,D）等々の所見が認められる. 今回は眼球偏位量が最 終視標到達時の 75〜110\% に相当するあのについて検討 し，それ以外のあのについては除外して正常限界を求め た.

\section{III 結 果}

表 1 亿各パラメーターについて視標点隇時間間隔 3 秒 の場合と 2 秒の場合の平均値と標準偏差を示した.

1. 潜時 (表 1, 図 7)

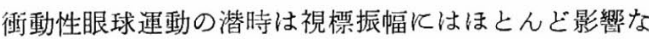
之また視標点滅時問々隔による差も少なく，ほほ一定 であった．ちなみに視標点時間間隔 3 秒の場合の総平均

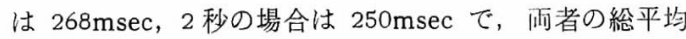
は $262 \mathrm{msec}$ である.ただし最初の視標点滅に対する潜 

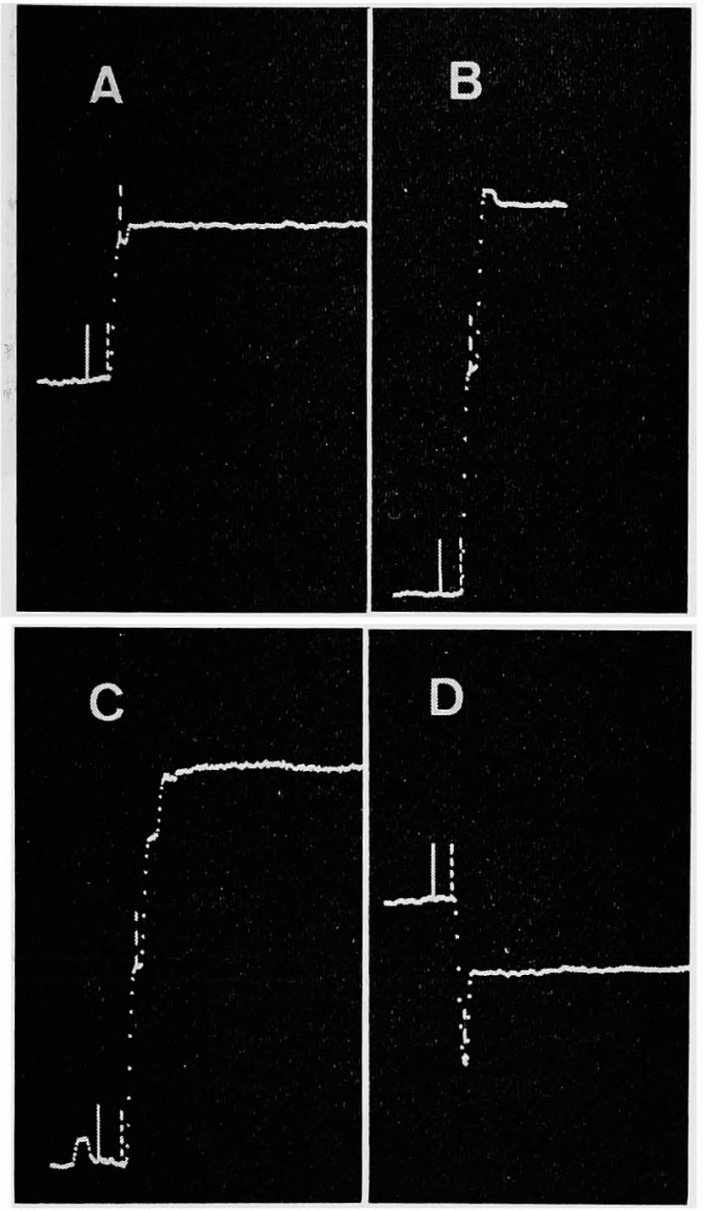

図 6 衝動性眼球運動の正常者における各種反 応波形（説明は本文参照）

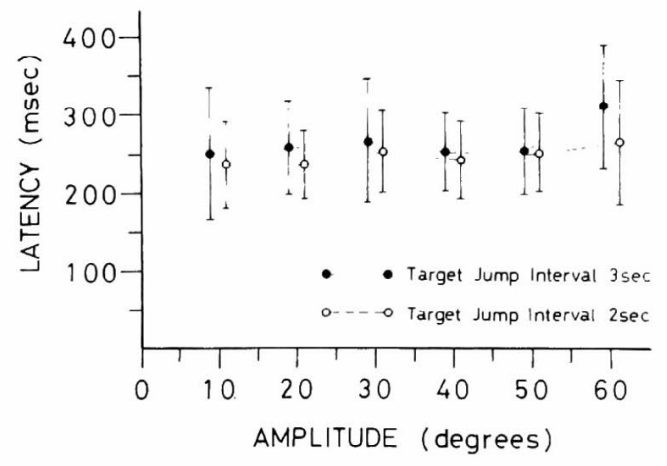

図 7 毢動性眼球運動の潜時
胿は平均約 $480 \mathrm{msec}$ と延長した。

2. 最高速度（表 1, 図 8)

最高速度は視標点隇時間間隔3秒ならびそ2秒の場合と あ視標振幅が大きくなるに従って眼球運動速度も速くな る傾向が認められ, 指数関数曲線に相似の曲線を示した.

3. 平均速度 (表 1, 図 9)

平均速度も最高速度とほほ同様の傾向を示し視標点滅 時間間隔による差は認められなかった。

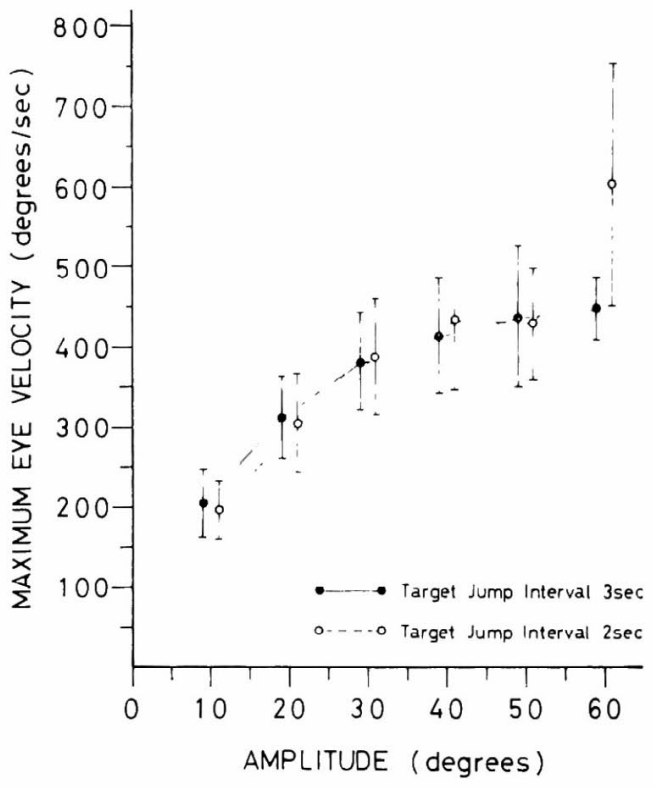

図 8 衝動性眼球運動の最高速度

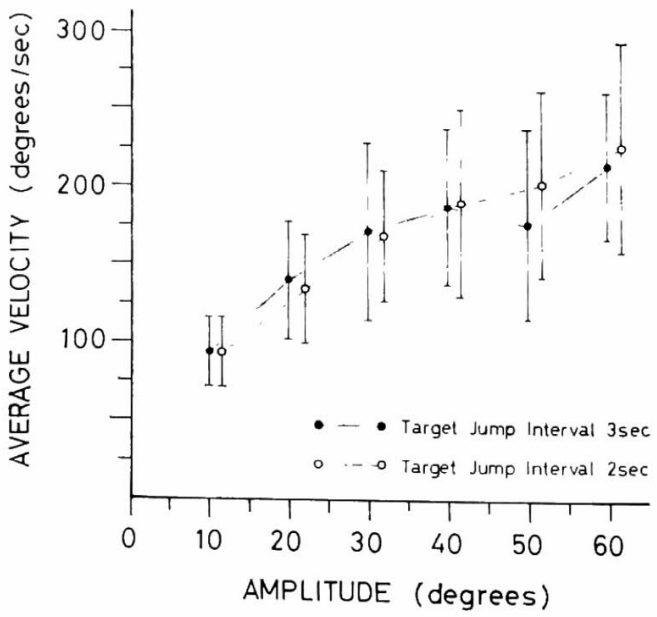

図 9 術動性眼球運動の平均速度 


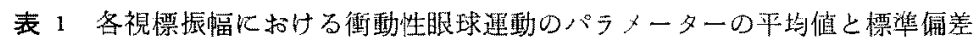

\begin{tabular}{|c|c|c|c|c|c|c|c|c|c|c|c|c|c|}
\hline \multicolumn{2}{|c|}{ 視標振幅 } & \multicolumn{2}{|c|}{$10^{\circ}$} & \multicolumn{2}{|c|}{$20^{\circ}$} & \multicolumn{2}{|c|}{$30^{\circ}$} & \multicolumn{2}{|c|}{$40^{\circ}$} & \multicolumn{2}{|c|}{$50^{\circ}$} & \multicolumn{2}{|c|}{$60^{\circ}$} \\
\hline \multicolumn{2}{|l|}{ 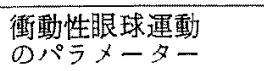 } & Mean & S.D. & Mean & S.D. & Mean & S.D. & Mean & S.D. & Mean & S.D. & Mean & S.D. \\
\hline 潜 & 3秒 & 259 & 89.8 & 263 & 62.1 & 270 & 82.3 & 255 & 58.8 & 255 & 65.1 & 311 & 84.0 \\
\hline (msec) & 2 杪 & 237 & 56.1 & 244 & 44.7 & 255 & 53.9 & 245 & 52.1 & 255 & 49.1 & 268 & 78.8 \\
\hline 最高速度 & 3秒 & 206 & 41 & 313 & 51 & 386 & 60 & 413 & 72 & 431 & 56 & 448 & 74 \\
\hline (deg/sec) & 2秒 & 199 & 40 & 304 & 60 & 388 & 73 & 433 & 67 & 437 & 90 & 607 & 149 \\
\hline 平均速度 & 3秒 & 96 & 22 & 140 & 39 & 172 & 52 & 188 & 48 & 175 & 59 & 216 & 44 \\
\hline$(\mathrm{deg} / \mathrm{sec})$ & 2秒 & 95 & 22 & 135 & 37 & 170 & 43 & 190 & 62 & 206 & 59 & 227 & 66 \\
\hline 持続 時 間 & 3 沙 & 111 & 27 & 136 & 47 & 181 & 71 & 224 & 71 & 263 & 105 & 269 & 61 \\
\hline (msec) & 2 秒 & 109 & 24 & 150 & 54 & 181 & 61 & 236 & 121 & 252 & 92 & 277 & 115 \\
\hline 最高速度到達 & 3秒 & 44.3 & 11.2 & 53.0 & 13.6 & 62.8 & 22,4 & 78.6 & 53.6 & 88.6 & 60.2 & 92.5 & 51.4 \\
\hline 時間 (msec) & 2 秒 & 43. 1 & 11.1 & 53.0 & 24.2 & 62.9 & 17.2 & 68.0 & 30.9 & 76.0 & 37.6 & 102.3 & 71.8 \\
\hline 眼球编位舅 & 3秒 & 10.0 & 2.1 & 18.9 & 2.9 & 28.5 & 3.2 & 39.0 & 4.5 & 48.7 & 5.4 & 56.0 & 5.3 \\
\hline (deg) & 2秒 & 9.8 & 1.9 & 18.1 & 2.9 & 28.4 & 4.1 & 39.1 & 5.6 & 47.5 & 5,4 & 57.1 & 6.5 \\
\hline
\end{tabular}

\section{4. 持続時間（表 1，図 10）}

衝動性眼球運動に要した時間は, 視標点堿特間間隔 3 秒，2秒上あに視標振幅が大きくなるに良って延長する 傾向を示し，雨者間に差は認められなかった。

5. 最高速度到達時間 MVT（表 1，図 11）

MVT 6持続時間同棁，視標点隇時間々隔による差は なく，視標振幅が大きくなるに徉って長時間を要した。

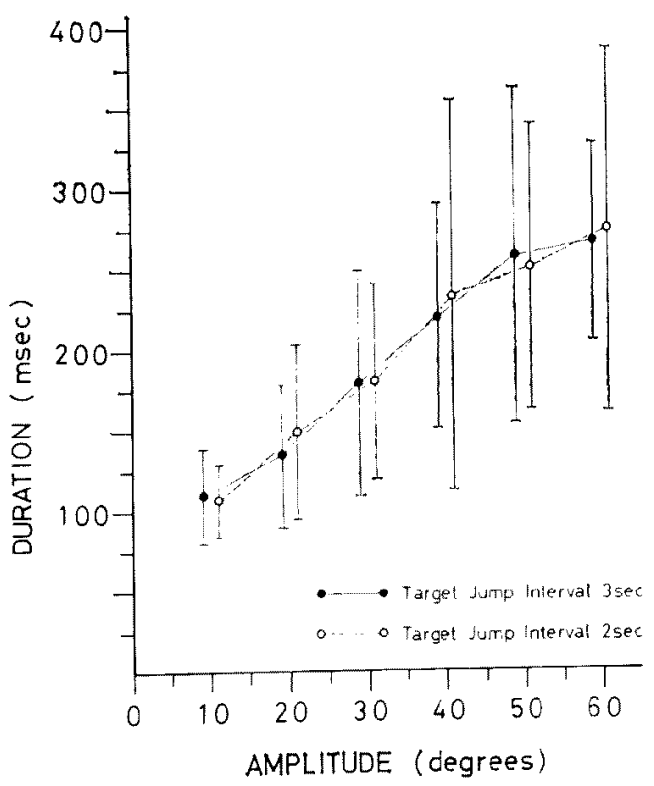

図 10 衝動性眼球運動の持続時間
しかし持結時間に比して視標振幅の增加に対する時間の 延長率は軽度であった。

6. 眼球偏位量（表 1，図 12)

眼球编位量屯視標点隇時間間隔儿よる影哣仗少なく， 全体として視摽振幅に対して undershootする傾向が認

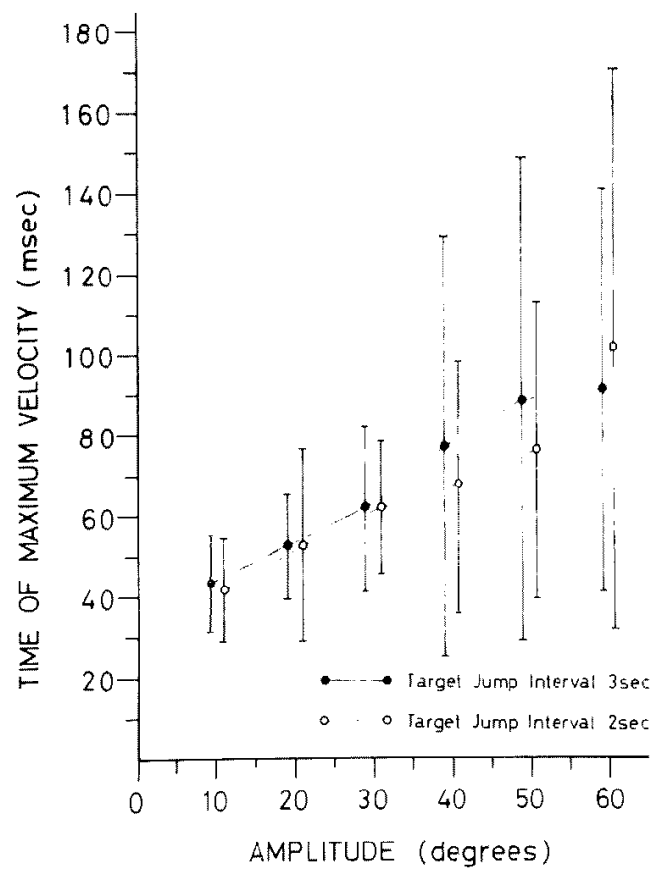

図 11 衝動性眼球運動の最高速度到達時間 


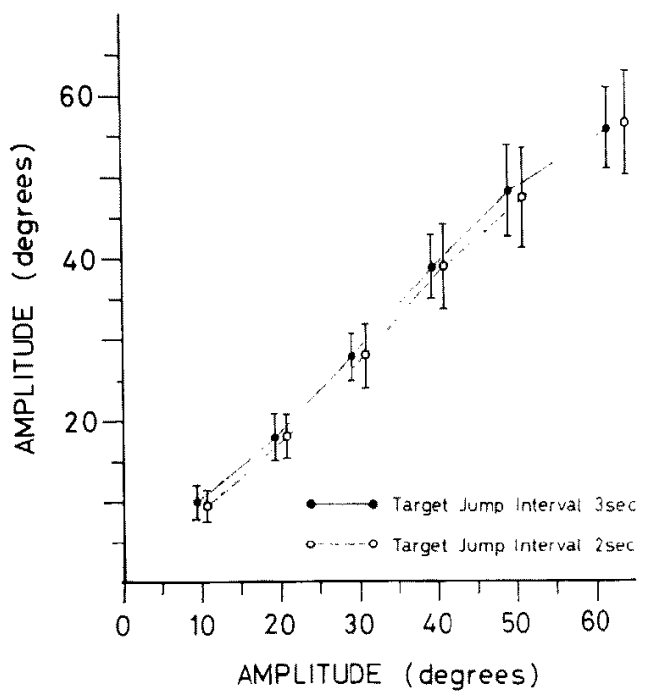

図 12 衝動性眼球運動の眼球偏位量（正確度）

縦蟿：眼球编位舅

横軸：視標刺激の腐位量

められるが視標振幅のほほ 95\%以上に相当し，かなり の正確さで視標をとらえているもの之思われた。

\section{IV 考 察}

Dodge (1903) 方眼球運動には 2 種類あり，視軸を ある点よりある点に変える時に起こる速い，不連続な眼 球運動(衝動性眼球運動)とゆっくり対象物を見る時に起 こる滑らかな連続的な眼球運動(滑動性眼球運動)がある 事を述べて以来，衝動性眼球運動について種々諭ぜられ ている. 近年, Westheimer (1954) ${ }^{15)}$ の最初の定量的 分析Kつついて Hyde (1959) ${ }^{9}$, Robinson (1964) ${ }^{11)} 5$ の生理学的研究により, 衝動性眼球連動の機構が解明さ れ，また Vossius (1961) ${ }^{14)}$, Yang and Stark(1962) ${ }^{17)}$, Cook and Stark $(1968)^{6)}$, Fuchs $(1971)^{82}$ bによる听 姦で衝動性眼球爑動の sampled deta model が作られ， 神経学的機構についての解明もなされている.最近はコ ンピェーターの導入により衙動性眼琲運動をより草く正 確に，客観的に定䥣化できるようになり，Baloh ${ }^{1933}$ ら により臨床的にす応用され始めている。

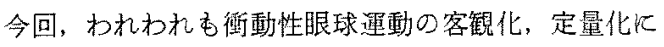
注目し，小型電算機（PDP-11/40）在使用して正常者に ついての衝動性眼球運動を検討した，本編では衡動性眼 球運動の潜時, 最高速度, 平均速度, 持綕時間, 最高速 度到達時間（MVT），正磼度（眼球俯位昜）の6項目に
つ以て, 視栖振偪存 $10^{\circ}, 20^{\circ}, 30^{\circ}, 40^{\circ}, 50^{\circ}, 60^{\circ}$ の

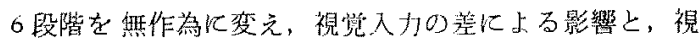

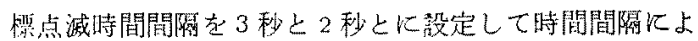

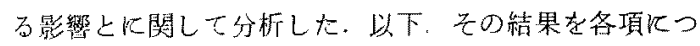
いて，他の報告者と比較榆討してみる，

\section{1。潜恃}

潜時は Westheimer $(1954)^{15}$, Robinson $(1964)^{11}$ によれば，又力振幅とは無関係で平均 $200 \mathrm{msec} て ゙ す$ るという. しかし Barta (1962) $)^{1)}$, White and Eason $(1962)^{16)}$, Saslow $(1967)^{12)}$ 視筧入力 $5^{\circ}$ でば度応塍 間 (潜時) は $200 \mathrm{msec}, 40^{\circ}$ では $250 \mathrm{msec}$ で視覚入力 が大きく江れば反応時間（潜㭙）も延長すると述へてい る。われわれの結果は視標点滅時間間隔，視標振幅には

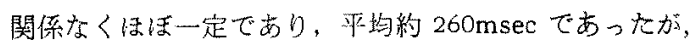
潜時の差は予測可能の有然や暗順応のレベルの差等によ

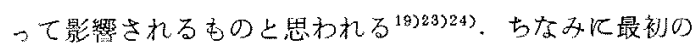

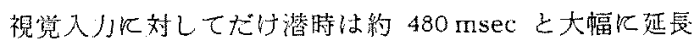
して扣り。予測可能の有盐が大きなウェイトをしめてい るすの上推祭される。

\section{2. 最高速度}

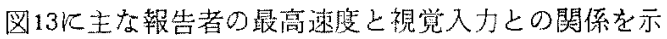

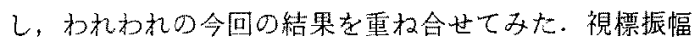
が約 $15^{\circ} \sim 20^{\circ}$ と小さい时には，最高速密はほぼ直線的 に大となるが，視標振幅がそれ以上となると最高速度は 直線的には増加せず，ゆるやかな力ーブを描いて增加 し，視標振幅とは指数関数曲線に似た相関を示す，実際 Baloh ${ }^{1)}$ は eye velocity $=\mathrm{K}(1-\exp \cdot[-$ amplitude / L $])$ の指数関数曲楾に近似すると郝先している。国上り各報 击者に扰石速度の差にばらつきが大きいのは, 刺激条

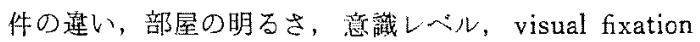
points 等の差など視覚（網膜中心窝、の入力）の差が影 留するのではないる推祭される゙、末た ENG 記録の 際の high cut filter

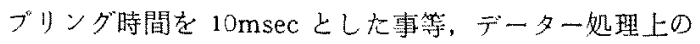
譟差も間題上なるものと等无的る。

3. 平均速度

平均速度む最高速搜上にぼ同様の傾问を示し, 視標点

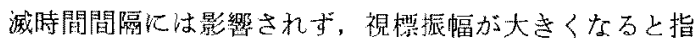
数関数曲線に近似した形で增加する ${ }^{12)}$ (表 1，图 9).

4. 持続時間

街動性眼球運動に扣ける持続時間は，やはり視標点滅 時間間隔による差はなく, 視標振幅上相関があり, 視標 振幅が大きくなるに従って延長し，ほぼ直楾的に堌加す 


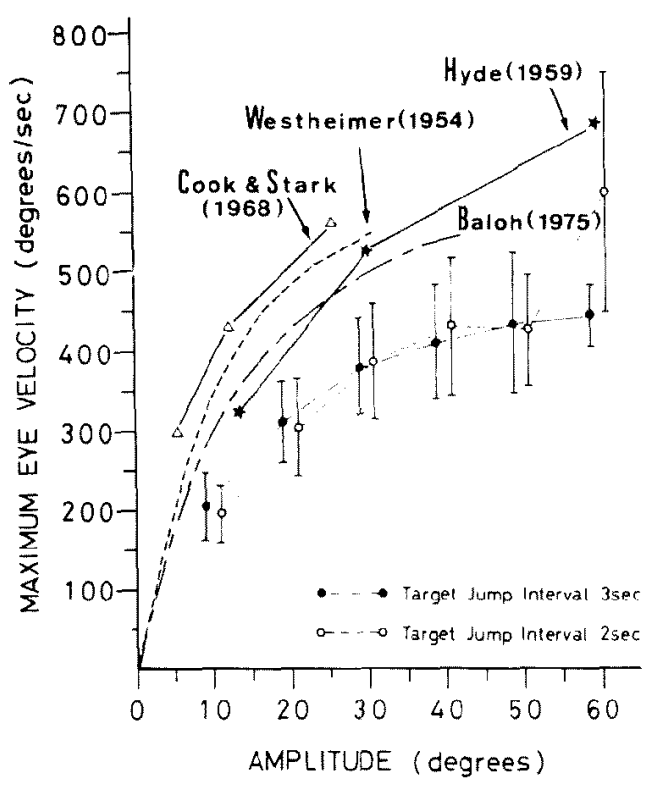

図 13 㣫動性眼球逛動の最高速度: 主な報告者との比較

る傾向を示しだ（表 1，図 10）。

\section{5. 最高速度到達時閭 (MVT)}

Hyde (1964) は) は視標振偪が大となると，加速時間仗 一定であるが，堿速時間は延長すると述へている。一方

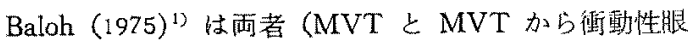
球運動の終りまでの時間) には差がなかったとしてい る、われわれの結果加らみてみる，MVT あ持続時間 同様，視標振幅が大きくなるに徉ってほほ占線的儿延長

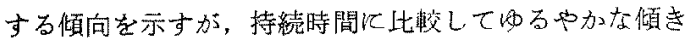
となっている(因 11)。つまり MVTょりも MVTか ら衝動性眼球運動の終りまでの時間に長時間を要して拉 り，Hyde ${ }^{9}$ の説を支持するあのと考えられる. しかし， 衝動性眼球運動の加速, 減速とい弓問題については今後

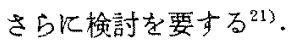

\section{6. 眼球偏位腽（衝動性眼球運動の正確度）}

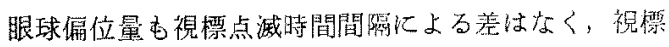
振幅亡相関し，視標振幅加大きくなるに良って眼球偏位 量も增大する。そしてその偏位鼠は視標振幅て対して全 体として， undershootする傾向を示しているが，視祭 振偪のほほ 95\%以上飞相当し，加なりの正確さで視標 をとらえているといえる(图 12). Westheimer (1954) 15), Robinson (1964) ${ }^{11)}$ 李視標振偪のほほ $9 / 10$ k相当 するとしているし，Baloh $(1977)^{3)}$ 毛約 90\%の正磼度

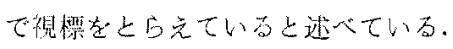

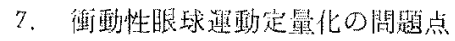

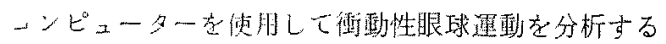

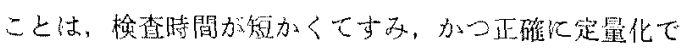

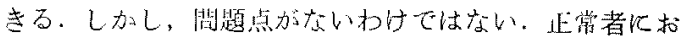

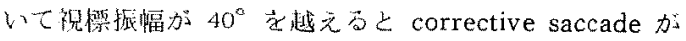
起るといか机てい名が占，尔の他 two saccade, three saccadeになる場合中，overshoot する場合もかり，1

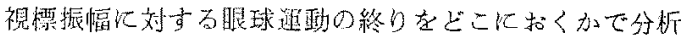

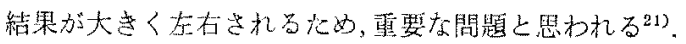

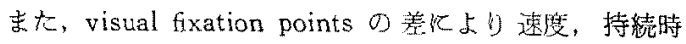
間，潜時等が影響される 度, 視嫩の光度等, 視覚入力の差による影響も無視でき ない，その他，疲当，意識レヘル等毛問題となる。さb に，鼠问䢞毁の項でも述べたが，ENG 記録の際のフィ ルター選执の問题, データー分析の際のサンプリング時

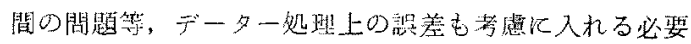
方市。

$$
\text { V市わりに }
$$

現在，視觉入力指標上して行な万检查法は視運動性

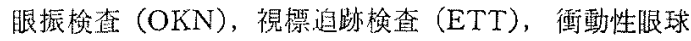
呈動梌查が行なわれているが，いず机も反応の左右差中 反応波形のパターンスより定性的手しくは半定量的儿結

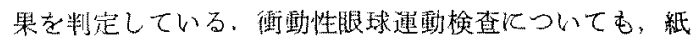
咲り速度を变化さ梿て，各パラメーターについて，反応

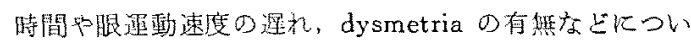

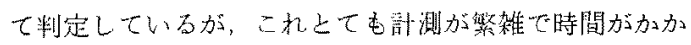
ること，不正碳であることなどより，臨床心用されるに はいたっていないのが奏情である。

本編飞和いてわれわれはコンピュータ一を用いて衝動

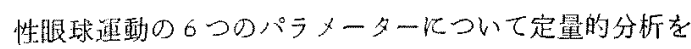

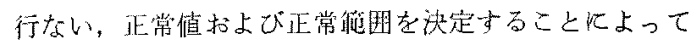

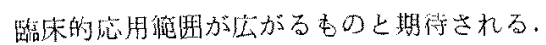

\section{VI 結語}

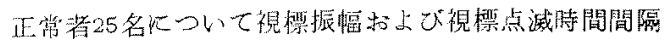

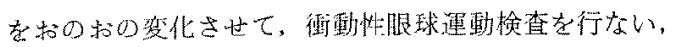

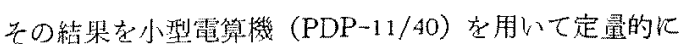
分析した。

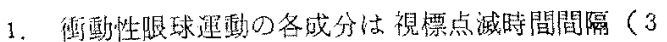
秒と2秒)儿上る差は認められず，す心て視樌振幅と相 略走示した。 
2. 潜時は視標振幅にかか力らず一定で，姓物 260 msec であった。ただし最初の入力振幅に好してだけは 䄪 $480 \mathrm{msec}$ 上延長した.

3、最高速度，平均速度は視標振幅之指数関数曲緗儿 似た相関を示した。

4. 持続時閐, 最高速度到澾時間は, 視標振幅が大き くなるとほ洁線的に延辰した。

5. 眼球偏位量（正確度）は視烈拢幅のほほ95\%以 上に相当し．か加の正確さで視標をとらえているすの といえる。

衝勘性眼球運動の定量的分析にはまだいくつかの問題 点があるが，今後检討を重ねることにより．眼球運動機 能検查に有用な情報を与光てくれるものと期待される。

\section{参若 文献}

1) Baloh $R W$, Slills $A W$ and Kumley $W E$ :

Quantitative measurement of saccade amptitude, duration, and velocity test. Neurology 25: 10651070, 1975.

2) Baloh $R W$, Konrad $H R$ and Sills $A W$ : The saccade velocity test. Neurology 25: 10711076,1976

3) Baloh $R W$, Honrubia $V$ and Sills $A$ : Eyetracking and optokinetic nystagmus. Results of quantitative testing in patients with well-defined nervous system lesions. Ann Otol 86: 108-114, 1978.

4) Bartz A: Eye movement latency, duration and response time as a function of angular displacement. J exp Psychol 64: 318-324, 1962.

5) Becker $W$ and Fuchs $A F$ : Further properties of the human saccadic system: Eye movements and correction saccades with and without visual fixation points. Vison Res 9: 1247-1258, 1969.

6) Cook $G$ and Stark $L$ : The human eye-movement mechanism: Experiments, modeling and model testing. Arch Ophthal 79: 428-436, 1968.

7) Dodge $R$ : Five types of eye movements in the horizontal meridian plane of the field of regard. Amer J Physiol 8: 307-329, 1903.

8) Fuchs $A F$ : The saccadic system. In Bach-yRita P. and Collins C C (ed.): The control of eye movements. New York and London, Acade- mic Press., 1971

9) Hyde J: Some characteristics of voluntary human ocular movements in the horizontal plane. Am. J. Ophthal 48: 85-94, 1959.

10) Johnson $L$ and Fleming $D$ : A model of model feedback control for saccadic eye movement. Proc 16th Ann Conf Eng Med Biol Balt., 5: 76 -77, 1963. (Fuchs ${ }^{82}$ 上り)

11) Robinson $D A$ : The mechanics of human saccadic eye movement. J Physiol 174: 245-264, 1964.

12) Saslow $M$ : Latency for saccadic eye movement. J opt Soc Amer 57: 1030-1033, 1967.

13) Stark $I$, Vossius $G$ and Young $L$ : Predictive control of eye tracking movements. IRE Trans HFE 3: 52-57, 1962. (Fuchs ${ }^{8)}$ 上 り)

14) Vossius G: Die Regelwegung des Auges. In Aufnahme und Verarbeitung von Nachrichten durch Organismen, ed. VDE. Stuttgrart., 1961. (Fuchs ${ }^{\text {s) }}$ 上り)

15) Westheimer $G$ : Mechanism of saccadic eye movements. Arch Ophthal 52: 710-724, 1954.

16) White $C$ and Eason $R$ : Latency and duration of eye movements in the horizontal plane. J opt Soc Amer 52: 210-213, 1962.

17) Young $L$ and Stark $L:$ A sampled-data model for eye-tracking movements. Quart Progr Rep Res Lab Electr M. I. T. 66: 370-384, 1962.

18）五十䛜秀一，水越鉄理，石川和光，山崎倩子，渡边

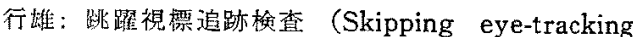
test） 定最的判定の試及 Equilibrium Res 37: 98-102, 1978.

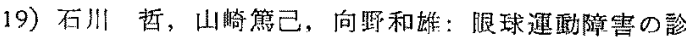

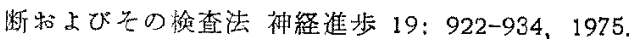

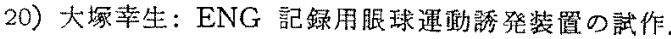
较正 (calibration), 注視・固視检查 (gaze \& fixation test) および路躍視標追跡検榃 (skipping eye tracking test SETT) への応用 耳楀矎床 64: 11231129,1971

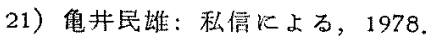

22）加滕 功，他： Rotary stepping switch K上句微

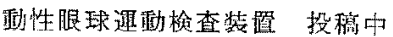

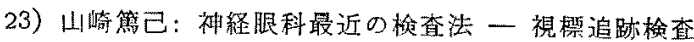


について 一 眼科 14: 972-982, 1972.

24）山崎篤己，石川椞：腿からみた脳神経疾患の猃断 法 日医事新報 2532：31-34，1972。

25）吉本 裕：点隇式視標追跡装置による衝動性眼球連 動湌査（その1）－正常所見について - 耳率臨床 66: 731-738, 1973.

26）吉本 裕: 眼球運動の急速成分（衝動性眼球運動, saccadic movement）の臨林的意義 一 新しい検查 法, 衝動性眼球運動検査の提案とともに一最新医 学 30: 285-293, 1975.

27）和田昌士, 坂田英治, 李 汝培, 栄木恭男, 杉田麟
也：通動視標追跡众査 ETT (Eye-tracking test) と跳躍連動視標追跡㭘查 SETT (Skipping eyetracking test）の守倩簀柬々臨床猃断的意㼁の検討 日耳奥 76：374-385，1973。

本論文の要旨は第37回日本平衡神経科学会（昭和53年 11月18日 奈良)に岎いて報告した。本研究は文部省科 学研究㸞の補助により行なわれた.

（原稿受付 昭和54.3.5 日）

別刷請求先 干990-23 山形市蔵王飯田字西の前 山形大学医学部耳粤咽喉科学教室 木村洋

\section{耳鳴治療㓮

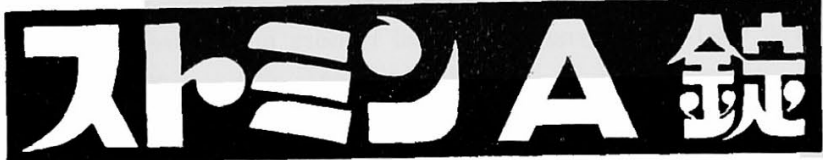

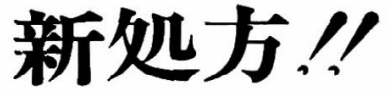

新発売!!

二重盲検法による薬効判定に基いて、 ストミンA錠(旧ストミンソンンネ錠)を 御提供します。

1 錠中 (裸錠) ニコチン酸アミド $30 \mathrm{mg}$ 、塩酸パ パヘリン $6 \mathrm{mg}$ 含有、通常 1 回 2 烷、1 日 3 回 投与する。

（包装）100錠・1,000錠 $\cdot 5,000$ 錠

【健保採用】【薬価】1 錠 $¥ 4.90$

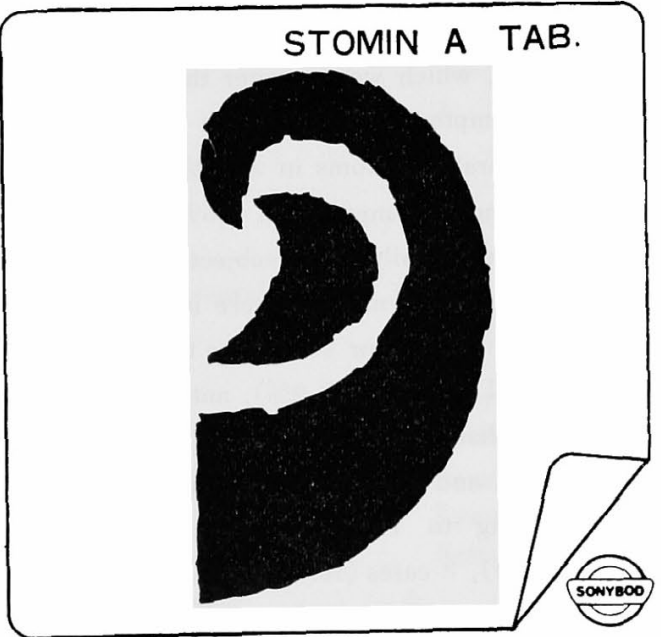

製造元ゾンネボード製薬株式会社 発売元鳥居薬 品株式会社 東京 八下子市散田町 291
東京 大阪 名古屋・福岡・札幌 